\title{
RESPONS TANAMAN JAHE MERAH (Zingiber officinale) TERHADAP EKSTRAK BAWANG MERAH DAN PUPUK HAYATI Trichoderma
}

\author{
Response of Red Ginger (Zingiber officinale) Plant to Trichoderma Shallot Extract and \\ Biological Fertilizer
}

\author{
Sutarman \\ Program Studi Agroteknologi - Fakultas Pertanian Universitas Muhammadiyah Sidoarjo \\ J1. Raya Gelam No, 250 Candi - Sidoarjo 61217 \\ Email: sutarman@umsida.ac.id
}

\begin{abstract}
ABSTRAK
Penelitian ini bertujuan untuk mengetahui respons pertumbuhan vegetatif anakan jahe merah (Zingiber officinale) terhadap pemberian ekstrak bawang merah dan pupuk hayati Trichoderma. Percobaan disusun secara faktorial dengan menggunakan rancangan acak lengkap (RAL). Faktor pertama adalah konsentrasi ekstrak bawang merah yang terdiri atas tiga level yaitu: 0 gr, 125 gr, dan 250 gr per liter ekstrak bawang merah; faktor kedua adalah pupuk hayati Trichoderma, terdiri atas: tanpa pupuk hayati dan dengan pupuk hayati Trichoderma. Tiap kombinasi perlakuan diulang sebanyak 4 kali, sehingga diperoleh 24 satuan percobaan. Variabel yang diamati adalah pertambahan tinggi tanaman $(\mathrm{cm})$, pertambahan jumlah daun, pertambahan diameter batang $(\mathrm{cm})$, bobot basah brangkasan (gr), dan bobot kering brangkasan (gr) pada 24-60 hari setelah anam (HST). Data dianalisis dengan sidik ragam pada taraf 5\% untuk mengetahu pengaruh perlakuan, Untuk mengeahui perbedaan antarperlakuan dilakukan uii BNJ 5\%. Hasil penelitian menunjukkan terdapat pengaruh interaksi yang nyata antara ekstrak bawang merah dan pupuk hayati Trichoderma terhadap pertambahan pertumbuhan tinggi anakan jahe merah pada 48 HST. Ekstrak bawang merah berpengaruh nyata hanya terhadap pertambahan tinggi tanaman pada 36 hari setelah tanam. Kedua faktor dan interaksinya tidak nyata terhadap jumlah daun, diameter batang, bobot basah, dan bobot kering brangkasan. Perlakuan konsentrasi ekstrak bawang merah 125 gr/l dan pupuk hayati Trichoderma menghasilkan respons rerata jumlah daun dan diameter batang yang tertinggi pada akhir pengamatan.
\end{abstract}

Kata kunci : ekstrak bawang merah, jahe merah, pertumbuhan vegetatif, pupuk hayati Trichoderma,

This study aims to determine the vegetative growth response of saplings of red ginger (Zingiber officinale) to the administration of red onion extract and Trichoderma biological fertilizer. Experiments were arranged factorially using a completely randomized design (CRD). The first factor is the concentration of red onion extract which consists of three levels, namely: $0 \mathrm{gr}, 125 \mathrm{gr}$, and $250 \mathrm{gr}$ per liter of shallot extract; the second factor is Trichoderma biological fertilizer, consisting of: without biological fertilizer and with Trichoderma biological fertilizer. Each combination of treatments was repeated 4 times, to obtain 24 experimental units. The variables observed were plant height $(\mathrm{cm})$, number of leaves, increase in stem diameter $(\mathrm{cm})$, stover wet weight (gr), and dry stover weight (gr) at 24-60 days after planting (DAP). Data were analyzed by variance at the level of 5\% to determine the effect of 
treatment, to find out the differences between treatments were carried out by $5 \%$ HSD. The results showed that there was a significant interaction effect between red onion extract and Trichoderma biofertilizer on the increase of high growth of red ginger tillers at 36 and 48 DAP. Both factors and their interactions were not significant for the number of leaves, stem diameter, wet weight, and dry stover weight. The treatment of $125 \mathrm{gr} / \mathrm{l}$ shallot extract and Trichoderma biofertilizer produced the highest response of the number of leaves and stem diameter at 60 DAP.

Keywords : red onion extract, red ginger, vegetative growth, Trichoderma biological fertilizer,

\section{PENDAHULUAN}

Jahe adalah rempah-rempah
penting di dunia yang banyak dibudidayakan di daerah tropis serta dikonsumsi juga sebagai obat (Prasad et al., 2015). Salah satu variannya adalah jahe merah (Zingiber officinale Rocs. var. Rubrum) banyak digunakan sebagai fitofarmaka dan menjadi komoditas ekspor.

Upaya peningkatan produksi jahe merah dilakukan bukan saja dengan cara perluasaan lahan pertanaman tetapi juga peningkatan kesuburan lahan dengan tetap memperhatikan efisiensi biaya produksi dan kesehatan tanah.

Aplikasi pupuk non kimia merupakan salah satu cara untuk meningkatkan kesuburan dan kesehatan tanah. Pemanfaatan pupuk hayati Trichoderma merupakan salah satu jawaban tantangan budidaya jahe merah tanpa bahan kimia. Trichoderma adalah fungi "soil borne" yang dapat diandalkan dalam meningkatkan kesuburan tanah sekaligus memberi perlindungan kesehatan tanaman, Peran penting Trichoderma mampu menghasilkan enzim-enzim penting seperti B-1,3-glukanase, selulase, dan peroksidase (Verma et al., 2007; Vinale et al., 2008; Saravanakumar et al., 2016) sehingga terbukti mampu mendegradasi bahan organik tanah (Ma et al., 2008; Guan, 2011; Hu et al., 2015) dan menghasilkan nutrisi esensial bagi untuk tanaman (Gravel et al., , 2007; Buysens et al., 2016); pada akhirnya akan meningkatkan produksi tanaman pada lahan kering (Hu et al., 2016; Ali, Mohammedand, dan Aboud, 2015), Berbagai jenis Trichoderma memiliki kemampuan tinggi dalam meghasilkan enzim kitinase (Chowdappa et al., 2013) sehingga dapat meningkatkan ketahanan tanaman terhadap penyakit dan melindungi tanaman dari serangan patogen.

Untuk mendorong pertumbuhan awal yang baik, pemberian senyawa yang bersifat sebagai pengatur pertumbuhan 
tanaman perlu dilakukan. Ekstrak bawang merah telah terbukti bermanfaat dalam mendorong pertumbuhan awal berbagai tanaman mengingat kandungan zat pemgatur tumbuh seperti auksin dan giberillin (Marfirani, 2014; Nababan, Gustianty, dan Efend, 2018). Namun demikian sejauh ini belum diketahui sejauhmana ekstrak bawang merah dapat berpengaruh pada pertumbuhan vegetatif jahe merah dan kemungkinannya adanya interkasi dengan fungi Trichoderma yang diaplikasikan di dalam tanah dalam memperngaruhi pertumbuhan tanaman. Ekstrak bawang merah mengandung flavonoid, quercetin, ascalin, dan saponin yang bersifat anti fungal (Wang dan Ng, 2002; (Barile et al., 2007). Belum diketahui sejauh mana ekstrak bawang merah ini dapat menghambat aktifitas Trichoderma yang diaplikasikan pada tanaman sebagai pupuk hayati. Untuk itu perlu dilakukan pengujian aplikasi ekstrak bawang merah yang diperlakukan pada awal atau menjelang tanam sebagai zenyawa pengatur tumbuh pada rimpang dan bakal tunas jahe merah yang media tanamnya sudah diberikan pupuk hayati Trichoderma.

Penelitian ini bertujuan untuk mengetahui pengaruh ekstrak bawang merah naungan dan aplikasi pupuk hayati Trichoderma serta interaksi pada kedua faktor tersebut terhadap respons pertumbuhan vegetatif awal tanaman jahe merah dalam bentuk tinggi tanaman, jumlah daun, diameter batang, bobot basah dan bobot kering.

\section{BAHAN DAN METODE}

\section{Rancangan Penelitian}

Penelitian dilaksanakan di Green House (5 m dpl.) Program Studi Agroteknologi Fakultas Pertanian Universitas Muhammadiyah Sidoarjo di Desa Gelam Kecamatan Candi Kabupaten Sidoarjo pada bulan Mei-September 2017. Perlakuan pada percobaan disusun secara faktorial dengan menggunakan rancangan acak lengkap. Sebagai faktor pertama adalah pupk hayati Trichoderma yang terdiri atas: tanpa Trichoderma atau kontrol (T0) dan Trichoderma isolat TcJro-02 (T2). Faktor kedua adalah konsentrasi ekstrak bawang merah yang terdiri atas: tanpa ekstrak bawang merah (E0), 125 gr (E1) dan 250 gr (E2) per liter. Dengan ulangan 4 kali, maka diperoleh 24 satuan percobaan.

\section{Pelaksanaan.}

Isolat Trichoderma Tc-Jro-01 sebagai bahan aktif pupuk hayati merupakan hasil isolasi tanah di lahan agroforestri di bagian kawasan pemangkuan hutan (BKPH Jatiorejo), Kesatuan Pemangkuan Hutan (KPH) Pasuruan di desa Ngembat, Kecamatan 
Jatirejo, Kabupaten Mojokerto, Propinsi Jawa Timur. Saat ini isolat Tc-Jro-01 menjadi koleksi Laboratorium Mikrobiologi Pertanian Fakultas Pertanian Universitas Muihammadiyah Sidoarjo.

Isolat ditumbuhkan dalam media PDA-m (Vargas Gill et al., 2009) selama 10 hari inkubasi. Kultur isolat Trichoderma tersebut dihaluskan dengan menggunakan mixer dan diencerkan hingga menjadi suspensi. Untuk mengetahui populasi isolat dalam satuan volume tertentu, maka dilakukan serangkaian pengenceran hingga $10^{8}$. Selanjutnya sebanyak $1 \mathrm{ml}$ dari suspensi tersebut diambil dengan menggunakan sirynge steril dan disemprotkan ke permukaan media PDA-m dalam cawan petri. Setelah tiga hari masa inkubasi, maka akan tampak titik koloni kehijauan di permukaan media dalam cawan yang menunjukkan kepadatan populasi per $\mathrm{ml}$ suspensi. Berdasarkan hasil populasi pengujian dengan cara pengenceran tersebut, maka dilakukan pengenceran atau penambahan air destilat streril agar diperoleh rata-rata populasi kedua macam isolat tersebut sama tiap $\mathrm{ml}$ suspensinya yaitu $0,5 \times 10^{8} \mathrm{cfu} / \mathrm{ml}$.

Untuk pembuatan media tanam, disiapkan tanah dan kompos. Tanah yang digunakan adalah jenis alfisol $(\mathrm{pH} 6,8)$ yang diambil dari lahan kering di Desa
Watukosek, Kecamatan Gempol, Kabupaten Pasuruan, Jawa Timur. Tanah dan kompos disterilisasi dengan menggunakan autoclave pada suhu $121{ }^{\circ} \mathrm{C}$ 1 atm selama 30 menit. Tanah yang digunakan sebagai media tanam tersebut diambil tersebut diambil Suspensi propagul Trichoderma Tc-Jro-01 yang sudha diperoleh, dituangkan ke dalam kompos steril dan kepadatannya diatur hingga menjadi 5 x $10^{7} \mathrm{cfu} / \mathrm{gr}$ kompos. Dalam tiap polibag yang berisi $5 \mathrm{~kg}$ tanah diberikan 200 gr kompos yang dicampur secara merata; dengan demikian populasi masing-masing isolat Trichoderma dalam medium tumbuh di tiap polibag adalah $2 \times 10^{6} \mathrm{cfu} / \mathrm{gr}$. Polibag yang sudah diberi pupuk hayati Trichoderma kemudian diinkubasi selama dua minggu sebelum penanaman rimpang benih jahe merah.

Ekstrak bawang merah diperoleh dengan cara menghancurkannya dengan blander dan disaring dengan lubang saringan $0,5 \mathrm{~mm}$. Untuk keperluan aplikasinya, maka dibuat suspensi ekstrak bawang merah dengan konsentrasi 125 gr/l dan 250 gr liter dan tanpa ekstrak bawang merah $(0 \mathrm{gr} / \mathrm{l})$ dengan pelarut atau pengencernya adalah air destilat.

Rimpang jahe merah (Zingiber officinale Rocs. var. Rubrum) diperoleh dari desa Popoh Kecamtana Wonoayu, Kabupten Sidoarjo. Benih dalam bentuk 
rimpang yang berukuran relatif sama merendamnya dalam ekstrak bawang merah selama 15 menit sesuai level perlakuan konsentrasi yaitu 250 gr/l, 125 gr/l, dan 0 gr/liter (kontrol). Rimpang diangkat dari rendaman dan menempatkannya ke dalam lubang tanam di tiap polibag sesuai perlakuan, kemudian menutupnya dengan tanah tipis-tipis sehingga yang muncul adalah tunasnya dan disiram dengan air steril. Tiap pagi dan sore hari masing-masing ke permukaan polibag disiram air dengan volume rata-rata $500 \mathrm{ml}$ atau hingga kondisi tanah basah.

\section{Pengamatan}

Pengamatan dilakukan tiap 12 hari terhadap pertambahan pertumbuhan tinggi tanaman $(\mathrm{cm})$, pertambahan jumlah daun, dan pertambahan diameter batang $(\mathrm{cm})$ pada $24,36,48$, dan 60 hari setelah tanam (HST); serta bobot basah dan bobot kering brangkasan tanaman pada 60 HST

\section{Analisis Data}

Data hasil pengamatan dianalisis dengan menggunakan sidik ragam pada taraf 5\% untuk mengetahui pengaruh perlakuan terhadap respons perrumbuhan tanaman jahe merah. Untuk mengetahui perbedaan antar perlakuan dilakukan uji Beda Nyata Jujur (BNJ) pada taraf 5\%.

\section{HASIL}

\section{Tinggi Tanaman}

Hasil analisis ragam terhadap pertambahan tinggi anakan jahe merah mulai 24 hingga 60 hari setelah tanam (HST) menunjukkan bahwa intraksi pupuk hayati Trichoderma dan ekstrak bawang merah berpengaruh sangat nyata $(\mathrm{p}<0,01)$ terhadap pertambahan tinggi tanaman pada 48 HST. Masing-masing faktor perlakuan tidak berpengaruh nyata terhadap pertambahan tinggi tanaman, kecuali ekstrak bawang merah berpengaruh sangat nyata $(\mathrm{p}<0,01)$ terhadap pertambahan tinggi tanaman pada 36 SHT.

Rerata pengaruh interaksi pupuk hayati Trichoderma dan konsentrasi ekstrak bawang merah terhadap pertambahan tinggi tanaman diperlihatkan pada Tabel 1. Rerata pertabahan tinggi tanaman sebagai respons anakan terhadap pemberian ekstrak bawang merah ditunjukkan pada Tabel 2.

Tabel 1. Rerata pertambahan dua belas harian tinggi anakan jahe merah sebagai respons terhadap ekstrak bawang merah dan pupuk hayati Trichoderma pada umur 48 hari setelah tanam $(\mathrm{cm})$ 


\begin{tabular}{|c|c|c|c|}
\hline \multirow[b]{2}{*}{$\begin{array}{l}\text { Konsentrasi ekstrak } \\
\text { bawang merah }\end{array}$} & \multicolumn{2}{|c|}{ Pupuk Hayati Trichoderma } & \multirow[b]{2}{*}{$\begin{array}{l}\mathrm{BNJ} \\
5 \%\end{array}$} \\
\hline & $\begin{array}{c}\text { Tanpa } \\
\text { Trichoderma } \\
\text { (T0) }\end{array}$ & $\begin{array}{c}\text { Trichoderma } \\
\text { (T1) }\end{array}$ & \\
\hline $0 \mathrm{~g} / \mathrm{l}(\mathrm{E} 0)$ & $\begin{array}{r}5,43 \text { a } \\
\text { A }\end{array}$ & $\begin{array}{rl}3,93 & b \\
B & \end{array}$ & \\
\hline $125 \mathrm{~g} / \mathrm{l}(\mathrm{E} 1)$ & $\begin{array}{c}2,83 \mathrm{a} \\
\mathrm{B}\end{array}$ & $\begin{array}{c}4,85 \text { a } \\
\text { A }\end{array}$ & 2,31 \\
\hline $250 \mathrm{~g} / \mathrm{l}(\mathrm{E} 2)$ & $\begin{array}{c}4,03 \text { a } \\
\mathrm{AB}\end{array}$ & $\begin{array}{c}4,63 \mathrm{a} \\
\mathrm{AB}\end{array}$ & \\
\hline BNJ $5 \%$ & & & \\
\hline
\end{tabular}

Keterangan: Angka yang diikuti oleh huruf kapital dan huruf kecil yang sama masing-masing pada kolom dan baris yang sama menunjukkan pengaruh ysng sama pada uji BNJ 5\%.

Tabel 2. Rerata pertambahan dua belas harian tinggi anakan jahe merah sebagai respons terhadap ekstrak bawang merah pada umur 36 hari setelah tanam $(\mathrm{cm})$

\begin{tabular}{cc}
\hline $\begin{array}{c}\text { Konsentrasi } \\
\text { ekstrak bawang } \\
\text { merah }\end{array}$ & $\begin{array}{c}\text { Tinggi } \\
\text { anakan } \\
(\mathrm{cm})\end{array}$ \\
\hline $0 \mathrm{~g} / \mathrm{l}(\mathrm{E} 0)$ & $2,97 \mathrm{~b}$ \\
$125 \mathrm{~g} / \mathrm{l}(\mathrm{E} 1)$ & $3,61 \mathrm{ab}$ \\
$250 \mathrm{~g} / \mathrm{l}(\mathrm{E} 2)$ & $4,49 \mathrm{a}$ \\
\hline BNJ 5\% & 1,22 \\
\hline
\end{tabular}

Keterangan: Angka yang diikuti oleh huruf kecil yang sama masing-masing pada kolom dan baris yang sama menunjukkan pengaruh ysng sama pada uji BNJ 5\%.

Secara keseluruhan pertmbahan tinggi tanaman yang diamati tiap 12 minggu sejak 24 hingga 60 HST diperlihatkan pada Tabel 3. Rerata respons pertambahan tinggi anakan sebagai respons terhadap pemberian pupuk hayati Trichoderma dan ekstrak bawang merah masing-masing diperlihatkan pada Gambar 1 dan 2.

Tabel 3. Rerata pertambahan dua belas harian tinggi tanaman sejak 24 hingga 60 HST (cm)

\begin{tabular}{lcccccc}
\hline Perlakuan & $\begin{array}{c}\text { Tinggi } \\
\text { anakan } \\
(12 \text { HST })\end{array}$ & 24 HST & 36 HST & 48 HST & 60 HST & $\begin{array}{c}\text { Tinggi } \\
\text { anakan } \\
\text { (60 HST) }\end{array}$ \\
\hline T0E0 & 3,00 & 1,80 & 2,25 & 5,43 & 5,00 & 19,40 \\
T0E1 & 3,15 & 1,50 & 1,93 & 2,83 & 4,33 & 14,88 \\
T0E2 & 3,28 & 2,90 & 3,20 & 4,03 & 5,15 & 20,78 \\
T1E0 & 3,13 & 1,95 & 1,93 & 3,93 & 4,83 & 17,85 \\
T1E1 & 3,63 & 2,60 & 2,95 & 4,85 & 5,15 & 21,00 \\
T1E2 & 3,98 & 2,90 & 3,10 & 4,63 & 5,70 & 21,70 \\
\hline
\end{tabular}




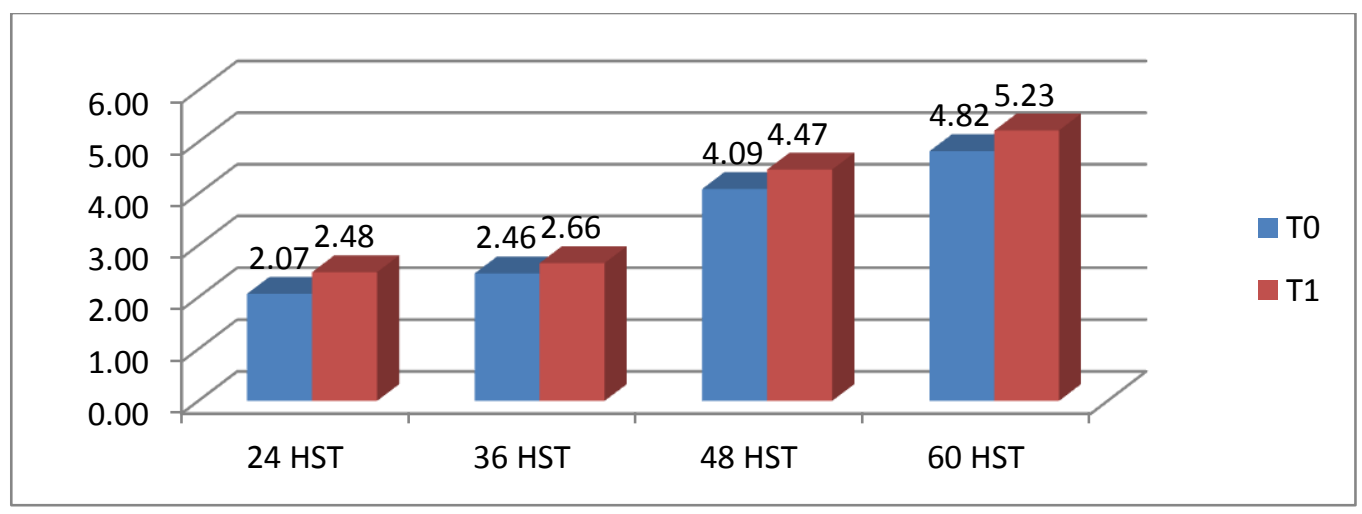

Gambar 1. Rerata pertambahan 12 harian tinggi anakan jahe merah sebagai respons pemberian pupuk hayati Trichoderma pada 24-60 hasri setelah tanam

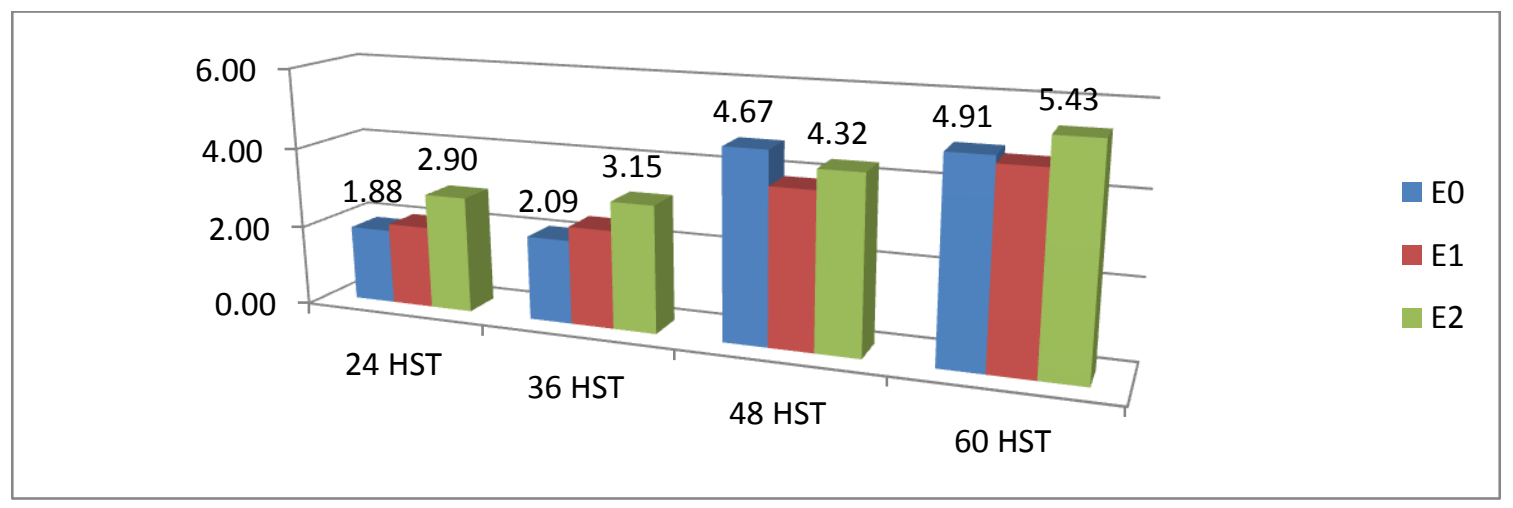

Gambar 2. Rerata pertambahan 12 harian tinggi anakan jahe merah sebagai respons pemberian ekstrak bawang merah pada 24-60 hasri setelah tanam

\section{Jumlah Daun}

Hasil analisis ragam terhadap pertabahan dua belas harian jumlah daun anakan tanaman jahe merah menunjukkan bahwa pupuk hayati Trichoderma dan konsentrasi ekstrak bawang merah serta interaksi di antar keduanya tidak berpengaruh nyata $(\mathrm{p}>0,05)$ terhadap pertambahan jumlah daun anakan pada 24-60 HST.

Rerata pengaruh interaksi pupuk hayati Trichoderma dan konsentrasi ekstrak bawang merah terhadap pertambahan dua belas harian jumlah daun anakan jahe merah diperlihatkan pada Tabel 4.

Tabel 4. Rerata pertambahan tiap 12 hari jumlah daun anakan jahe merah pada 24-60 HST $(\mathrm{cm})$

\begin{tabular}{|c|c|c|}
\hline Perlakuan & $\begin{array}{l}\text { Jumlah } \\
\text { daun } \\
\text { anakan }\end{array}$ & Waktu pengamatan \\
\hline
\end{tabular}




\begin{tabular}{lcccccc} 
& $(12 \mathrm{HST})$ & 24 HST & 36 HST & 48 HST & 60 HST & (60 HST) \\
\hline T0E0 & 3,00 & 1,80 & 5,43 & 5,43 & 5,00 & 19,40 \\
T1E0 & 3,15 & 1,50 & 2,83 & 2,83 & 4,33 & 14,88 \\
T0E1 & 3,28 & 2,90 & 4,03 & 4,03 & 5,15 & 20,78 \\
T1E1 & 3,13 & 1,95 & 3,93 & 3,93 & 4,83 & 17,85 \\
T0E2 & 3,63 & 2,60 & 4,85 & 4,85 & 5,15 & 21,00 \\
T1E2 & 3,98 & 2,90 & 4,63 & 4,63 & 5,70 & 21,70 \\
\hline
\end{tabular}

Rerata pertambahan jumlah daun

anakan sebagai respons terhadap pemberian pupuk hayati Trichoderma dan ekstrak bawang merah masing-masing diperlihatkan pada Gambar 3 dan 4.

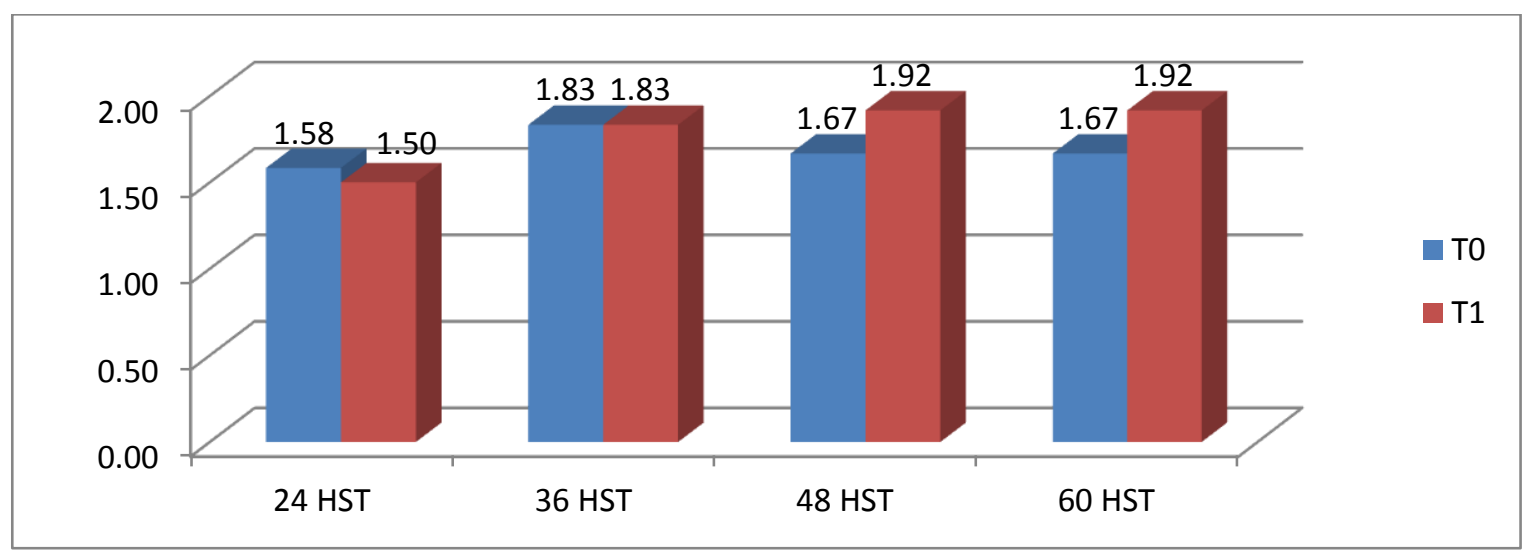

Gambar 3. Rerata pertambahan 12 harian jumlah daun anakan jahe merah sebagai respons terhadap pupuk hayati Trichoderma 24-60 hasri setelah tanaman (HST)

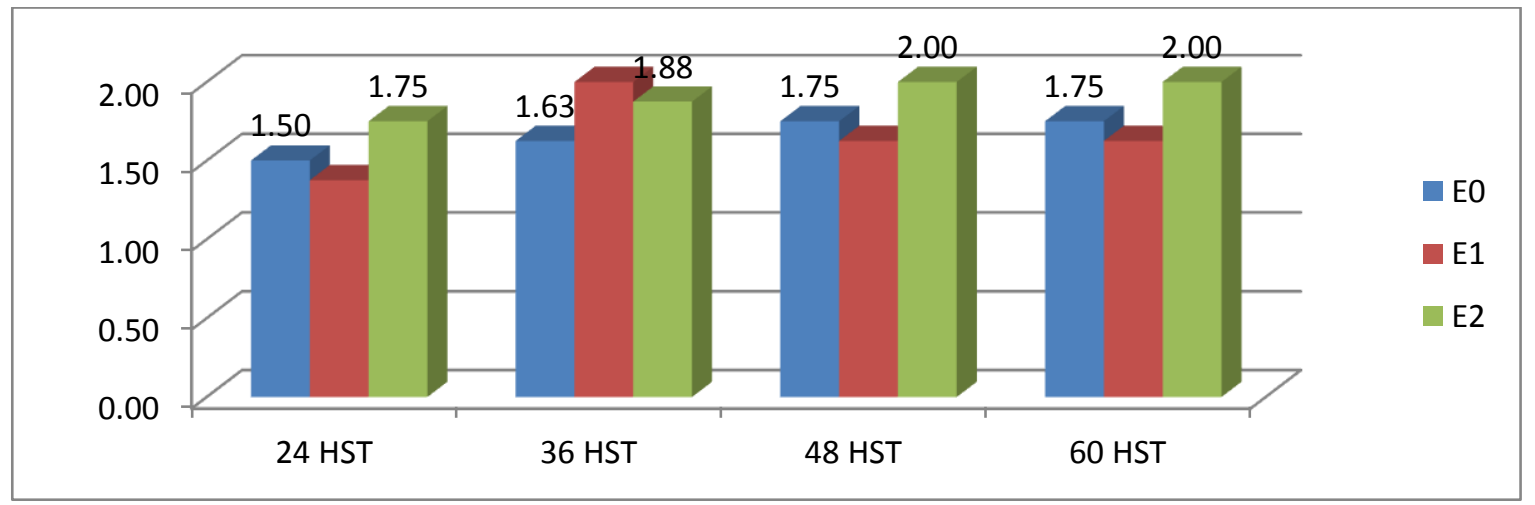

Gambar 4. Rerata pertambahan 12 harian jumlah daun anakan jahe merah sebagai respons terhadap ekstrak bawang merah 24-60 hasri setelah tanaman (HST) 


\section{Diamaeter Batang}

Pupuk hayati Trichoderma dan konsentrasi ekstrak bawang merah serta interaksi di antar keduanya tidak berpengaruh nyata $(p>0,05)$ terhadap bobot basah brangkasan anakan tanaman jahe merah pada $60 \mathrm{HST}$.
Rerata pengaruh interaksi pupuk hayati Trichoderma dan konsentrasi ekstrak bawang merah terhadap pertambahan dua belas harian diameter batang anakan jahe merah dapat dilihat pada Tabel 5.

Tabel 5. Rerata pertambahan dua belas harian diameter batang anakan jahe merah pada 24 $60 \mathrm{HST}(\mathrm{mm})$

\begin{tabular}{lcccccc}
\hline Perlakuan & $\begin{array}{c}\text { Diameter } \\
\text { batang } \\
\text { anakan } \\
(12 \mathrm{HST})\end{array}$ & 24 HST & 36 HST & 48 HST & 60 HST & $\begin{array}{c}\text { Diameter } \\
\text { batang } \\
\text { anakan } \\
(60 \mathrm{HST})\end{array}$ \\
\hline T0E0 & 2,93 & 0,42 & 0,71 & 0,54 & 1,04 & 5,65 \\
T1E0 & 3,12 & 0,27 & 0,61 & 0,38 & 0,74 & 5,01 \\
T0E1 & 3,12 & 0,43 & 0,75 & 0,77 & 0,61 & 5,67 \\
T1E1 & 2,80 & 0,46 & 0,61 & 0,98 & 0,76 & 5,60 \\
T0E2 & 3,25 & 0,66 & 0,55 & 0,61 & 1,25 & 6,31 \\
T1E2 & 3,55 & 0,55 & 0,57 & 0,48 & 0,94 & 6,08 \\
\hline
\end{tabular}

Rerata pertambahan dua belas harian diameter batang anakan tanaman jahe merah sebagai respons terhadap pemberian pupuk hayati Trichoderma dan ekstrak bawang merah masing-masing diperlihatkan pada Gambar 5 dan 6.

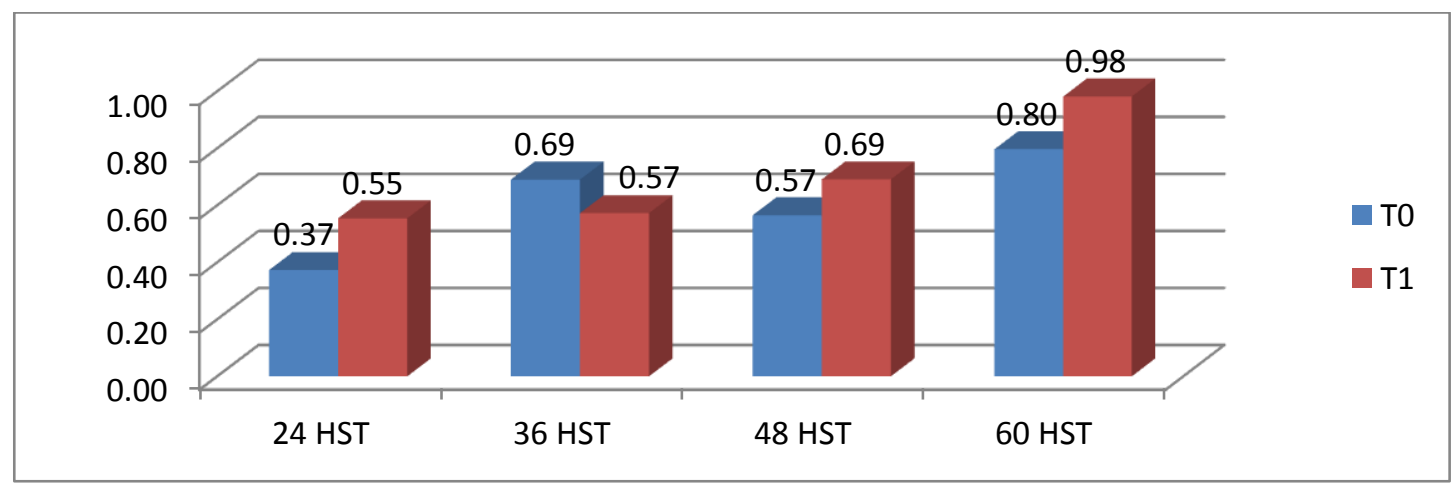

Gambar 5. Rerata pertambahan 12 harian diameter batang anakan jahe merah sebagai respons terhadap pupuk hayati Trichoderma 24-60 hari setelah tanam (HST) (mm) 


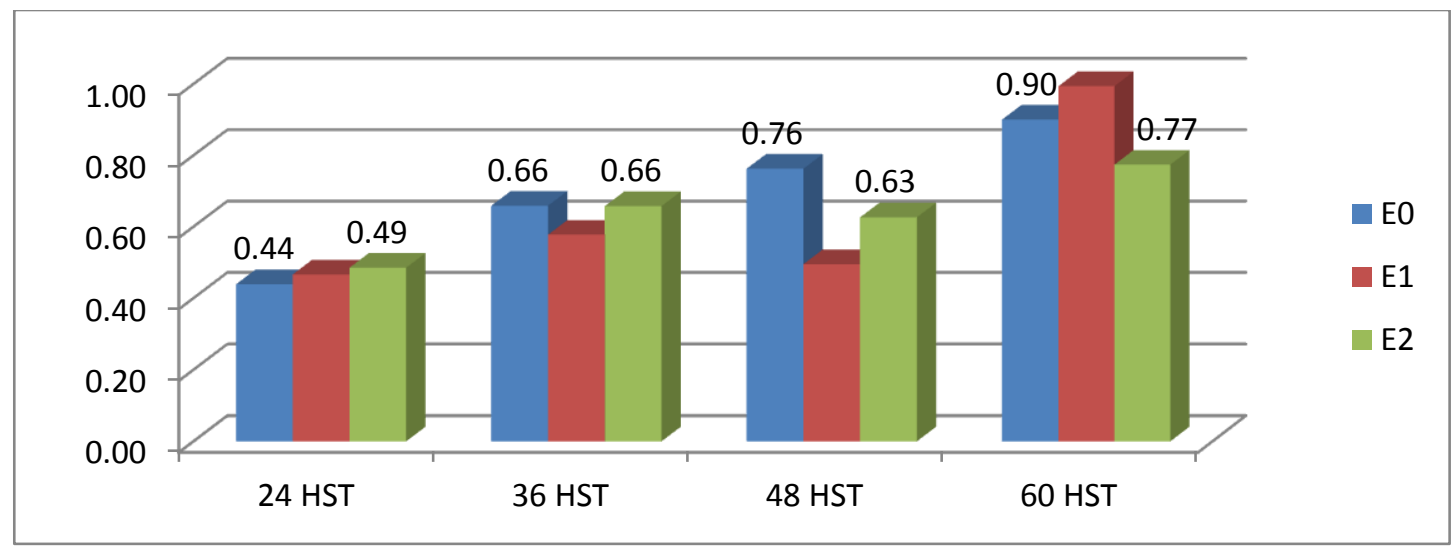

Gambar 6. Rerata pertambahan 12 harian diameter batang anakan jahe merah sebagai respons terhadap ekstrak bawang merah 24-60 hari setelah tanam (HST) (mm)

\section{Bobot Basah Brangkasan}

Hasil analisis ragam pengaruh pupuk hayati Trichoderma dan konsentrasi ekstrak bawang merah serta interaksinya tidak nyata $(p>0,05)$ terhadap bobot basah brangkasan anakan tanaman jahe merah 60 HST.

Tabel 6. Rerata bobot basah brangkasan anakan jahe merah sebagai respons ekstrak bawang merah dan pupuk hayati Trichoderma (gr) dan persentase peningkatannya terhadap kontrol pada 60 HST (gr)

\begin{tabular}{ccc}
\hline Perlakuan & $\begin{array}{c}\text { Bobot } \\
\text { basah } \\
\text { brangkasan } \\
\text { (gr) }\end{array}$ & $\begin{array}{c}\text { Peningkatan } \\
\text { terhadap } \\
\text { kontrol }\end{array}$ \\
\hline T0E0 & 20,33 & - \\
T1E0 & 14,48 & $-28,8 \%$ \\
T0E0 & 18,20 & $25,7 \%$ \\
T0E2 & 16,70 & $-8,2 \%$ \\
T1E1 & 19,70 & $18,0 \%$ \\
T1E2 & 19,53 & $-0,9 \%$ \\
\hline
\end{tabular}

Rerata pengaruh kombinasi perlakuan antara pupuk hayati Trichoderma dan konsentrasi ekstrak bawang merah serta pengaruh masingmasing faktor terhadap bobot basah brangkasan anakan jahe merah diperlihatkan pada Tabel 6 dan 7 .

Tabel 7. Rerata bobot basah brangkasan anakan jahe merah masing-masing sebagai respons ekstrak bawang merah (gr) dan pupuk hayati Trichoderma serta persentase peningkatannya terhadap kontrol pada 60 HST (gr)

\begin{tabular}{ccc}
\hline Perlakuan & $\begin{array}{c}\text { Bobot } \\
\text { basah } \\
\text { brangkasan } \\
\text { (gr) }\end{array}$ & $\begin{array}{c}\text { Peningkatan } \\
\text { terhadap } \\
\text { kontrol }\end{array}$ \\
\hline T0 & 17,67 & - \\
T1 & 18,64 & $5,5 \%$ \\
\hline E0 & 18,51 & - \\
E1 & 17,09 & $-7,7 \%$ \\
E2 & 18,86 & $10,4 \%$ \\
\hline
\end{tabular}


Bobot Kering Brangkasan

Hasil analisis ragam pengaruh pupuk hayati Trichoderma dan konsentrasi ekstrak bawang merah serta interaksinya tidak nyata $(p>0,05)$ terhadap bobot kering brangkasan anakan tanaman jahe merah 60 HST.
Rerata pengaruh kombinasi perlakuan antara pupuk hayati Trichoderma dan konsentrasi ekstrak bawang merah serta pengaruh masingmasing faktor terhadap bobot kering brangkasan anakan jahe merah diperlihatkan pada Tabel 8 dan 9.

Tabel 8. Rerata bobot kering brangkasan anakan jahe merah sebagai respons ekstrak bawang merah dan pupuk hayati Trichoderma (gr) dan persentase peningkatannya terhadap kontrol pada 60 HST (gr)

\begin{tabular}{ccc}
\hline Perlakuan & $\begin{array}{c}\text { Bobot } \\
\text { kering } \\
\text { brangkasan } \\
\text { (gr) }\end{array}$ & $\begin{array}{c}\text { Peningkatan } \\
\text { terhadap } \\
\text { kontrol }\end{array}$ \\
\hline T0E0 & 1,70 & - \\
T1E0 & 1,08 & $-36,8 \%$ \\
T0E0 & 1,55 & $44,2 \%$ \\
T0E2 & 1,40 & $-9,7 \%$ \\
T1E1 & 1,68 & $19,6 \%$ \\
T1E2 & 1,68 & $0,0 \%$ \\
\hline
\end{tabular}

Tabel 9. Rerata bobot kering brangkasan anakan jahe merah masing-masing sebagai respons ekstrak bawang merah (gr) dan pupuk hayati Trichoderma serta persentase peningkatannya terhadap kontrol pada 60 HST (gr)

\begin{tabular}{ccc}
\hline Perlakuan & $\begin{array}{c}\text { Bobot } \\
\text { kering } \\
\text { brangkasan } \\
\text { (gr) }\end{array}$ & $\begin{array}{c}\text { Peningkatan } \\
\text { terhadap } \\
\text { kontrol }\end{array}$ \\
\hline T0 & 1,44 & \\
T1 & 1,58 & $9,8 \%$ \\
\hline E0 & 1,55 & - \\
E1 & 1,38 & $-11,3 \%$ \\
E2 & 1,61 & $17,3 \%$ \\
\hline
\end{tabular}




\section{PEMBAHASAN}

\section{Ekstrak bawang merah} berpengaruh nyata terhadap pertambahan dua belas harian tinggi tanaman pada 36 HST. Peningkatan konsentrasi memberikan peningkatan perrtambahan tinggi tanaman (Tabel 2). Namun demikian pengaruh ini tidak nyata pada 48 dan 60 HST. Hal ini menunjukkan bahwa senyawa-senyawa di dalam ekstrak bawang yang di antaranya mengandung prekusor zat pengatur tumbuh bagi tanaman, terserap dalam rimpang dan tunas memberikan efeknya hingga 36 HST. Auksin yang terkandung dalam ekstrak bawang merah (Marfirani, 2014) dan terserap dalam tunas dan rimpang jahe lebih mendorong laju pertumbuhan tunas. Hal ini juga didukung oleh kecukupan intensitas cahaya yang masuk ke permukaan tajuk tanaman. Cahaya akan mempengaruhi kerja senyawa pengatur pertumbuhan baik auksin dan sitokin dalam perannya terhadap pertumbuhan akar (Fett-Neto et al., 2001; Wynne.dan McDonald, .2002) dan pertumbuhan batang (Agulló-Antón et al., 2011). Cahaya akan mempengaruhi tingkat induksi auksin yang berperan dalam metabolisme yang melibatkan fotooksidasi (Normanly, Slovin, dan Cohen, 2004; Ding, 2011; Sassi et al., 2012). Sementara itu sukrosa memainkan peran penting dalam pertumbuhan jaringan muda (Massoumi et al., 2017).

Pertumbuhan tinggi juga dipengaruhi oleh peran Trichoderma yang ditunjukkan bersama-sama dengan ekstrak bawang merah adanya interaksi yang nyata dalam mempengaruhi pertumbuhan tinggi tanaman (Tabel 1 dan 3). Trichoderma menstimulasi aktivitas indole acetic acid (Gravel, 2007) bagi tanaman dan berperan dalam mempromosikan pertumbuhan vegetatif awal hinga produksi biomassa tanaman (Buysens et al., 2016; Youssef et al., 2016). Selain itu kompos sebagai "carrier" isolat Trichoderm sebagai bahan aktif juga berperan dalam meningkatkan pertumbuhan tanaman (Lasmini et al., 2015) melalui proses dekomposisi bahan oganik oleh Trichoderma.

Interaksi Trichoderma dan ekstrak bawang merah tidak nyata pada pertambahan jumlah daun dan diameter batang pada semua waktu pengamatan (Tabel 4 dan 5). Demikian juga terhadap bobot basah dan bobot kering brangkasan anakan (Tabel 6 dan 8). Hal ini diduga karena ekstrak bawang merah hanya memberikan pengaruhnya pada awal pertumbuhan tanaman yang secara fisik hanya tampak pada pertambahan tinggi tanaman pada 48 HST. 
Meskipun tidak nyata ( $p>, 0,05)$, aplikasi Trichoderma memberikan rerata pertambahan pertumbuhan vegetatif tinggi (Gambar 1), jumlah daun (Gambar 3), diameter batang (Gambar 5), bobot basah dan bobot kering brangkasan (Tabel 7 dan 9). Trichoderma dapat meningkatkan $5,5 \%$ bobot basah brangkasan dan 9,8\% bobot kering brangkasan.

Secara keseluruhan meski ekstrak bawang merah tidak berpengaruh nyata $(\mathrm{p}<0,01)$ meningkatkan pertumbuhan vegetatif tanaman pada awal pertumbuhan (hingga 36 HST), namun pemberian ekstrak bawang merah menunjukkan rerata pertumbuhan vegetatif yang lebih tinggi dibandingkan dengan kontrol dalam hal tinggi tanaman (Gambar 2) dan jumlah daun (Gambar 4). Ekstrak bawang merah dapat meningkatkan $10,4 \%$ bobot basah brangkasan dan $17,3 \%$ bobot kering tanaman. Hal ini diduga bahwa nutrisi di dalam ekstrak bawang merah berperan dalam meningkatkan metabolisme sel tanaman tanaman dan pembentukan struktural jaringan tanaman.

Dari percobaan ini tampak bahwa ekstrak bawang merah ternyata tidak bersifat anti fungal terhadap Trichoderma, hal ini ditunjukkan dengan performa anakan jahe merah yang lebih baik dibandingkan tanpa Trichoderma baik dalam hal pertambahan tinggi tanaman, jumlah daun, dan diameter batang (Gambar 1, 3, dan 5) serta bobot basah dan bobot kering brangkasan, (Tabel 7 dan 9).

\section{KESIMPULAN}

Terdapat pengaruh interaksi yang nyata antara ekstrak bawang merah dan pupuk hayati Trichoderma yang diberikan pada awal penanaman terhadap pertambahan pertumbuhan tinggi anakan jahe merah pada 48 hari setelah tanam, namun tidak nyata pada 24. 36, dan 60 hari setelah tanam. Ekstrak bawang merah berpengaruh nyata hanya terhadap pertambahan tinggi tanaman pada 36 hari setelah tanam. Baik ekstrak bawang merah maupun pupuk hayati Trichoderma serta interaksinya tidak berpengaruh nyata terhadap jumlah daun, diameter batang, bobot basah, dan bobot kering brangkasan. Pemeberian konsentrasi ekstrak bawang merah $125 \mathrm{gr} / \mathrm{l}$ dan pupuk hayati Trichoderma pada awal tanam menghasilkan respons tertinggi dalam rerata jumlah daun dan diameter batang pada 60 hari setelah tanam.

\section{DAFTAR PUSTAKA}

Agulló-Antón MA, Sánchez-Bravo J, Acosta M \& Druege U. 2011. Auxins or sugars: what makes the difference in the adventitious rooting of stored carnation cuttings? J Plant Growth Regul, 30, 100-113

Ali HZ, Mohammedand RS \& Aboud HM. 2015. Efficiency of organic matter levels and bio fungus Trichoderma 
harzianum on cucumber plant. IOSR J. Agric. Vet. Sci. Ver. I, 8 (6): 2319-2372.

Barile E, Bonanomi G, Antignani V, Zolfaghari B, Sajjadi SE, Scala F \& Lanzotti V. 2007. Saponins from Allium minutiflorum with antifungal activity. Phytochemistry, 68, 596603

Buysens C, César V, Ferrais F, Dupré de Boulois H \& Declerck S. 2016. Inoculation of Medicago sativa cover crop with Rhizophagus irregularis and Trichoderma harzianum increases the yield of subsequently-grown potato under low nutrient conditions. Appl. Soil Ecol., 105, 137-143.

Chowdappa P, Kumar SPM, Lakshmi MJ \& Upreti KK. 2013. Growth stimulation and induction of systemic resistance in tomato against early and late blight by Bacillus subtilis OTPB1 or Trichoderma harzianum OTPB3. Biol. Control, 65 (1): 109-117.

Ding Z, Galván-Ampudia CS, Demarsy E, Langowski L, Kleine-Vehn J \& Fan Y. 2011. Light-mediated polarization of the PIN3 auxin transporter for the phototropic response in Arabidopsis. Nat Cell Biol, 13, 447-452.

Fett-Neto AG, Fett JP, Goulart LWV, Pasquali G, Termignoni RR \& Ferreira AG. 2001. Distinct effects of auxin and light on adventitious root development in Eucalyptus saligna and Eucalyptus globules. Tree Physiol., 21, 457-464

Gravel V, Antoun H, \& Tweddell RJ. 2007. Growth stimulation and fruit yield improvement of greenhouse tomato plants by inoculation with Pseudomonas putida or Trichoderma atroviride: Possible role of indole acetic acid (IAA). Soil Biol. Biochem., 39 (8): 1968-1977.

Guan CY. 2011. The Development direction of the oilseed rape industry in China. Grain Sci. Technol. Econ. $36,5-6$.

Hu X, Roberts DP, Xie L, Maul JE, Yu C, Li Y, Zhang Y, Qin L \& Liao X. 2015. Components of a rice-oilseed rape production system augmented with Trichoderma sp. Tri-1 control Sclerotinia sclerotiorum on oilseed rape. Phytopathology 105, 13251333.

Hu X, Roberts DP, Xie L, Yu C, Li Y, Qin L, Hu L, Zhang Y \& Liao X. 2016. Use of formulated Trichoderma sp. Tri-1 in combination with reducedrates of chemical pesticide for control of Sclerotinia sclerotiorium on oilseed rape. Crop Protection, 79, 124-127.

Lasmini SA, Kusuma Z, Santoso M \& Abadi AL. 2015. Application Of organic and inorganic fertilizer improving the quantity and quality of shallot yield on dry land. Int. J. Sci. Technol. Res., 4 (4): 4-7.

Marfirani M. 2014. Pengaruh pemberian berbagai konsentrasi filtrat umbi bawang merah dan Rootone F terhadap pertumbuhan stek melati "Rato Ebu". Lentera Bio., 3(1): 7376.

Massoumi M, Krens FA, Visser RGF \& De Klerk JMG. 2017. Etiolation and flooding of donor plants enhance the capability of Arabidopsis explants to root Plant Cell Tiss Organ Cult. 130, 531-541 DOI 10.1007/s11240-017-1244-1

Ma XH, Feng JX, Chen Y, Chen JC \& Zhou GM. 2008. Occurrence and characterization of dimethachlon insensitivity in Sclerotinia sclerotiorum in Jiangsu Province of China. Plant Dis., 93 (1): 36-42.

Nababan RS, Gustianty LR \& Efendi E. 2018. Effect of the organic plant growth regulator (PGR) on growth and yield of some mustard varieties (Pai-Tsai) (Brassica juncea L.). 
Bernas Agricultural Research Journal. 14 (2): 124-33

Normanly J, Slovin JP \& Cohen JD. 2004. Auxin biosynthesis and metabolism. In: Davies PJ (ed) Plant hormones: biosynthesis. signal transduction action. Kluwer Academic Publishers, Dordrecht. pp 36-62

Prasad SS, Desai A, Shah C, Patel K, Dumator C, Vajpeyee SK \& Bhavsar VH. 2015. To investigate the effect of ginger (Zingiber officinale roscoe) on pendular intestine motility of rat. IJPSR. 6 (9): 4053-4057.

Saravanakumar K, Yu C, Dou K, Wang M, Li Y, and Chen J. 2016. Synergistic effect of Trichoderma-derived antifungal metabolites and cell wall degrading enzymes on enhanced biocontrol of Fusarium oxysporum $\mathrm{f}$. sp. cucumerinum. Biol. Control, 94, 37-46.

Sassi. M.. Lu. Y.. Zhang. Y.. Wang. J.. Dhonukshe. P.. \& Blilou. I. 2012. COP1 mediates the coordination of root and shoot growth by light through modulation of PIN1-and PIN2-dependent auxin transport in Arabidopsis. Development, 139, 3402-3412

Vargas Gil S, Pastor S, and March GJ. 2009. Quantitative isolation of biocontrol agents Trichoderma spp., Gliocladium spp. and actinomycetes from soil with culture media. Microbiol. Res., 164 (2): 196-205.

Verma M, Brar SK, Tyagi RD, Surampalli RY, and Valéro JR. 2007. Antagonistic fungi, Trichoderma spp.: Panoply of biological control. Biochem. Eng. J., 37 (1): 1-20.

Vinale F, Sivasithamparam K, Ghisalberti EL, Marra R, Barbetti MJ, Li H, Woo SL \& Lorito M. 2008. A novel role for Trichoderma secondary metabolites in the interactions with plants. Physiol. Mol. Plant Pathol. $72,80-86$.

Wang HX dan Ng TB (2002). Ascalin, a new anti-fungal peptide with human immunodeficiency virus type 1 reverse transcriptaseinhibiting activity from shallot bulbs. Peptides 23: 1025-1029.

Wynne.J..\& McDonald. M.2002 Adventitious root formation in woody plant tissue: influence of light and indole-3-butiricacid (IBA) on adventitious root induction in Betula pendula. In Vitro Cell Dev Biol Plant, 38, 210-212

Youssef SA, Tartoura KA, Abdelraouf GA 2016 Evaluation of Trichoderma harzianum and Serratia proteamaculans effect on disease suppression, stimulation of ROSscavenging enzymes and improving tomato growth infected by Rhizoctonia solani, Biological Control 100,79-86. 